\title{
Glucose metabolism disorders in patients with non-functioning adrenal adenomas - single-centre experience
}

\author{
Zaburzenia metabolizmu glukozy u pacjentów z hormonalnie nieczynnymi \\ gruczolakami nadnerczy — doświadczenie jednego ośrodka
}

\author{
Katarzyna Krzyżewska, Ewa Niemczuk, Bartosz Jakub Myśliwiec, Roman Junik \\ Department of Endocrinology and Diabetology, Nicolaus Copernicus University in Torun, Collegium Medicum in Bydgoszcz
}

\begin{abstract}
Introduction: The presence of glucose metabolism disorders and their possible correlation with degree of cortisol secretion were evaluated in patients with non-functioning adrenal incidentalomas (NFAIs).

Material and methods: The study group consisted of 131 patients with hormonally inactive adrenal incidentalomas. In each patient, besides hormonal and radiological evaluation, was assessed for fasting glucose and insulin concentrations, and the oral glucose tolerance test (OGTT) was performed in all participants without previous history of glucose disturbances. The HOMA-IR, QUICKI, and TyG indices were calculated.

Results: Diabetes was diagnosed in 30.5\% of the studied group. Among glucose tolerance abnormalities, impaired fasting glucose (IFG) was found in $23.7 \%$, impaired glucose tolerance (IGT) in $4.6 \%$, and combined IFG and IGT in $11.5 \%$. Normoglycaemia was recognised in $29.8 \%$ of NFAIs patients. The occurrence rate of glucose aberrations increased with age. There was a significant difference in all insulin resistance indices shown between normoglycaemic patients and those with impairments in glucose tolerance. There was no significant correlation between fasting glucose, insulin resistance indices, and adrenal tumour size or degree of cortisol secretion.

Conclusions: The prevalence of diabetes and impaired fasting glucose among NFAIs patients is much higher than in the general population. Therefore, patients with incidentally discovered adrenal tumours should be tested for glucose tolerance. (Endokrynol Pol 2017; 68 (4): 416-421)

Key words: non-functioning adrenal adenoma, diabetes, impaired fasting glucose, impaired glucose tolerance
\end{abstract}

\section{Streszczenie}

Wstęp: Chorych z nieczynnymi hormonalnie incydentaloma nadnerczy (NFAI, non-functioning adrenal incidentaloma) zbadano pod kątem obecności zaburzeń metabolizmu i ich potencjalnych korelacji z poziomem sekrecji kortyzolu.

Materiał i metody: Badana grupa składała się ze 131 chorych z nieczynnymi hormonalnie incydentaloma nadnerczy. U każdego pacjenta oprócz oceny czynności hormonalnej i badań radiologicznych zmierzono glikemię na czczo oraz stężenie insuliny na czczo, a u osób bez zaburzeń gospodarki węglowodanowej w wywiadzie wykonano doustny test tolerancji glukozy (OGTT, oral glucose tolerance test). Obliczono wskaźniki HOMA-IR, QUICKI i TyG.

Wyniki: U 30,5\% badanych rozpoznano cukrzycę. U części chorych stwierdzono inne zaburzenia gospodarki węglowodanowej —u 23,7\% nieprawidłową glikemię na czczo (IFG, impaired fasting glucose), u 4,6\% nieprawidłową tolerancję glukozy (IGT, impaired glucose tolerance), a u 11,5\% skojarzenie IFG i IGT. Normoglikemię stwierdzono u 29,8\% pacjentów z NFAI. Częstość zaburzeń metabolizmu glukozy wzrasta z wiekiem. Wykazano istotną różnicę wartości wszystkich wskaźników insulinooporności między osobami z normoglikemią a pacjentami z nieprawidłowościami w zakresie tolerancji glukozy. Nie zaobserwowano istotnych korelacji między glikemią na czczo ani wskaźnikami insulinooporności a wielkością guza nadnerczy lub poziomem sekrecji kortyzolu.

Wnioski: Częstość występowania cukrzycy i nieprawidłowej glikemii na czczo u chorych z NFAI była znacznie wyższa niż w populacji ogólnej. Dlatego u chorych z przypadkowo wykrytymi guzami nadnerczy należy wykonać test tolerancji glukozy. (Endokrynol Pol 2017; 68 (4): 416-421)

Słowa kluczowe: nieczynny hormonalnie gruczolak nadnerczy, cukrzyca, nieprawidłowa glikemia na czczo, nieprawidłowa tolerancja glukozy

\section{Introduction}

In recent years, imaging technique improvement has led to an increase in the number of adrenal incidentalomas (AIs). Although different authors have used various definitions, the majority of them agree that $\mathrm{AI}$ is a mass discovered by diagnostic testing or treatment for unrelated disorders. By definition, patients with AIs do not show signs and symptoms of hormonal hypersecretion. However, even subtle forms of hormonal excess, especially cortisol secretion, may be associated with or be a marker of premature morbidity and mortality [1]. Moreover, patients with adrenal masses considered as hormonally inactive by endocrine evaluation often suffer from hypertension, dyslipidaemia, glucose intolerance, and obesity, all parameters closely linked to 
insulin resistance [2]. There is a continuing dilemma of whether a metabolic disturbance is seen more often in non-functioning adrenal incidentalomas (NFAIs) or whether it is a result of undetectable glucocorticoid hypersecretion. It has been proposed that NFAIs might be an unrecognised manifestation of metabolic syndrome $[3,4]$.

The aim of the study was to appraise the abnormalities in carbohydrate metabolism in consecutive patients with non-functioning adrenal adenomas and their possible correlation with degree of cortisol secretion.

\section{Material and methods}

The study group consisted of 131 consecutive patients with adrenal incidentalomas diagnosed between November 2014 and February 2016 at the Department of Endocrinology and Diabetology of University Hospital No. 1 in Bydgoszcz. Inclusion criteria considered:

- normal overnight low-dose dexamethasone suppression test ( $1 \mathrm{mg}$, orally, at 11 p.m. and measurement of serum cortisol at 8 a.m. the following morning) when morning cortisol fell below $1.8 \mu \mathrm{g} / \mathrm{dL}$;

- when post-dexamethasone serum cortisol concentration was over $1.8 \mu \mathrm{g} / \mathrm{dL}$ the absence of cortisol excess in other tests was required:

- normal 24-hour urinary free cortisol, morning adrenocorticotropin (ACTH), and midnight cortisol measurements,

- normal plasma renin activity and aldosterone levels during postural change,

- normal 24-hour urinary excretion of catecholamines,

- CT characteristics suggested adenoma (lesions with a radiation attenuation coefficient $\leq 10 \mathrm{HU}$ ).

An oral glucose tolerance test (OGTT) was performed in all participants without previous history of glucose disturbances. The fasting insulin level and glycated haemoglobin (HbA1c) were assessed as well. Insulin resistance and insulin sensitivity were evaluated using the HOMA-IR and QUICKI indices with the following validated formulas: homeostasis model assessment - HOMA-IR = fasting insulin $(\mu \mathrm{IU} / \mathrm{ml})$ $x$ fasting glucose $(\mathrm{mmol} / \mathrm{L}) / 22.5$ and the quantitative insulin sensitivity check index - QUICKI $=1 /[\log$ fasting insulin $(\mu \mathrm{IU} / \mathrm{mL})+\log$ fasting glucose $(\mathrm{mg} / \mathrm{dL})]$ [5]. An alternative insulin resistance (IR) estimator was used also, such as the triglyceride glucose (TyG) index, calculation of which was based on fasting plasma glucose and triglyceride. TyG index correlated with adiposity, and metabolic and atherosclerosis markers related to IR, and it presented good correlations with euglycaemic clamp. The TyG index was calculated as
Ln [fasting triglycerides $(\mathrm{mg} / \mathrm{dL}) \times$ fasting glucose $(\mathrm{mg} /$ $/ \mathrm{dL}) / 2][6,7]$.

Patients with fasting glucose concentration $\geq 100$ $\mathrm{mg} / \mathrm{dL}$ but $<126 \mathrm{mg} / \mathrm{dL}$ were considered as having impaired fasting glucose (IFG). Patients with two-hour post-load glucose level $\geq 140 \mathrm{mg} / \mathrm{dL}$ but $<200 \mathrm{mg} / \mathrm{dL}$ were considered as having impaired glucose tolerance (IGT). Diagnosis of diabetes was established if the subject had a prior diagnosis or had been treated with hypoglycaemic agents. The patients received $75 \mathrm{~g}$ OGTT and were diagnosed with diabetes mellitus if the glucose value was $\geq 200 \mathrm{mg} / \mathrm{dL}$ after two hours. Currently, Diabetes Poland (PTD) does not recommend measuring the haemoglobin A1c level to diagnose diabetes in the Polish population due to inadequate quality control of laboratory methods and unclear cut-off values of HbA1c [8]. However, following American Diabetes Association guidelines, a haemoglobin A1c range of $5.7 \%$ to $6.4 \%$ may indicate individuals with an increased chance of developing diabetes [9]. There was also observed a progressively increased risk of diabetes in subjects with TyG index levels of 8.31 and more [10]. In another study participants were classified into the metabolically obese but normal weight (MONW) and characterised with higher susceptibility to type 2 diabetes and cardiovascular diseases with TyG index above 8.82 for men and 8.73 for women [11]. The normal HOMA-IR range was $<2.5$. The reported values of QUICKI were $0.382 \pm$ 0.007 for non-obese, $0.331 \pm 0.010$ for obese, and 0.304 \pm 0.007 for diabetic individuals [5].

\section{Statistical analysis}

The measured parameters were checked for normality of distribution by the Shapiro-Wilk test. Values are presented as mean \pm standard deviation (SD) or median ( $25^{\text {th }}$ and $75^{\text {th }}$ percentiles) if not normally distributed. A comparison of the variables was performed using the ANOVA with Tukey post hoc test and the Kruskal-Wallis ANOVA test. The relationship between parameters was tested with Spearman's correlation. P values $<0.05$ were defined as statistically significant.

\section{Results}

Of the 131 patients (79 females and 52 males) with adrenal incidentalomas (99 unilateral and 32 bilateral, with mean diameter $21 \mathrm{~mm}), 92(70.2 \%)$ had glucose disturbances (Fig. 1). Forty participants $(30.5 \%)$ were classified as having diabetes mellitus (eight newly diagnosed cases). Among the glucose intolerance group impaired fasting glucose (IFG) was diagnosed in 31 cases, impaired glucose tolerance (IGT) in six cases, and combined IFG and IGT in 15 cases. Normoglycaemia was recognised in 39 patients $(29.8 \%)$. 


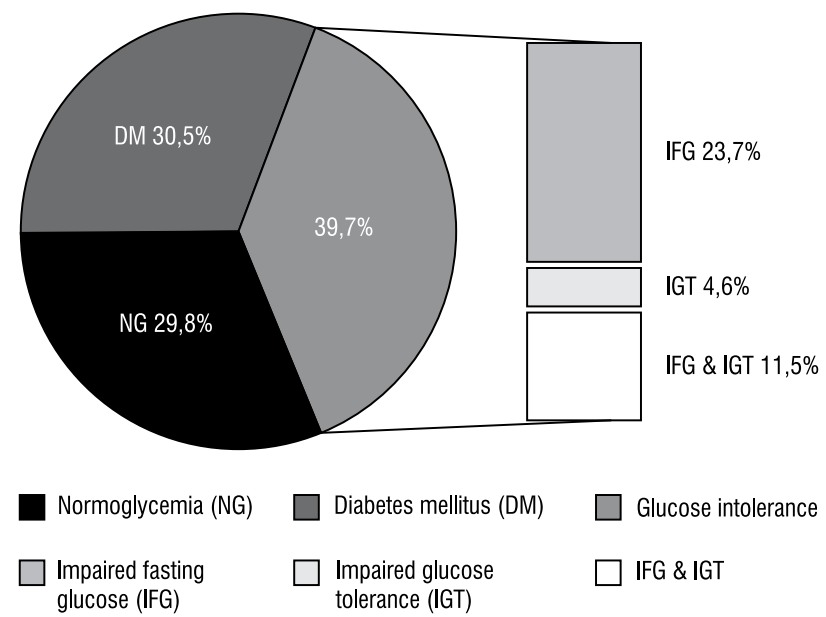

Figure 1. Prevalence of glucose disturbances in the studied group Rycina 1. Występowanie zaburzeń gospodarki węglowodanowej w badanej grupie

When normoglycaemic patients and with impairments in glucose tolerance were compared, no significant differences in sex, tumour size $(p=0.1587)$, midnight serum cortisol ( $p=0.2974), 24$-hour urinary free cortisol $(p=0,2842)$, plasma ACTH $(p=0.2566)$, and post-dexamethasone serum cortisol $(p=0.8040)$ or fasting insulin concentration $(p=0.1213)$ were detected.

The groups showed statistically significant differences in age (normoglycaemic vs. glucose intolerance group $\mathrm{p}=0.0347$; normoglycaemic vs. diabetes mellitus group $\mathrm{p}<0.0001)$ (Fig. 2), waist circumference $(\mathrm{p}=$ $0.0189 ; \mathrm{p}=0.0037$ in the above compared subgroups), and BMI (normoglycaemic vs. diabetes mellitus group $p=0.0015)$. The average age of patients with diabetes mellitus was $67.4 \pm 8.2$ years, whereas the average age of those with normoglycaemia was $58.8 \pm 8.3$ years. The highest prevalence of diabetes $(\geq 50 \%)$ was found among females aged $\geq 70$ years (Fig. 3) and males aged $\geq 60$ years (Fig. 4). In contrast, there was no case of diagnosed diabetes among patients under 50 years of age. About $87 \%$ of patients with diabetes mellitus and $86 \%$ of those with glucose intolerance were overweight or obese with abdominal fat distribution.

The median $\left(25^{\text {th }}\right.$ and $75^{\text {th }}$ percentiles) of HOMA-IR in patients with normoglycaemia, glucose intolerance, and overt diabetes was 1.74 (1.28; 2.77), 2.84 (1.87; 3.71), and $2.58(1.50 ; 4.20)$, respectively. The median QUICKI ( $25^{\text {th }}$ and $75^{\text {th }}$ percentiles) in the abovementioned subgroups was 0.305 (0.304; 0.307), 0.299 (0.298; 0.301), and $0.296(0.290 ; 0.300)$, respectively. The mean value of TyG index in compared subjects was $8.57 \pm 0.50$, $8.90 \pm 0.39$, and $9.01 \pm 0.40$. There was a significant difference in all insulin resistance indices shown between normoglycaemic and glucose intolerance groups

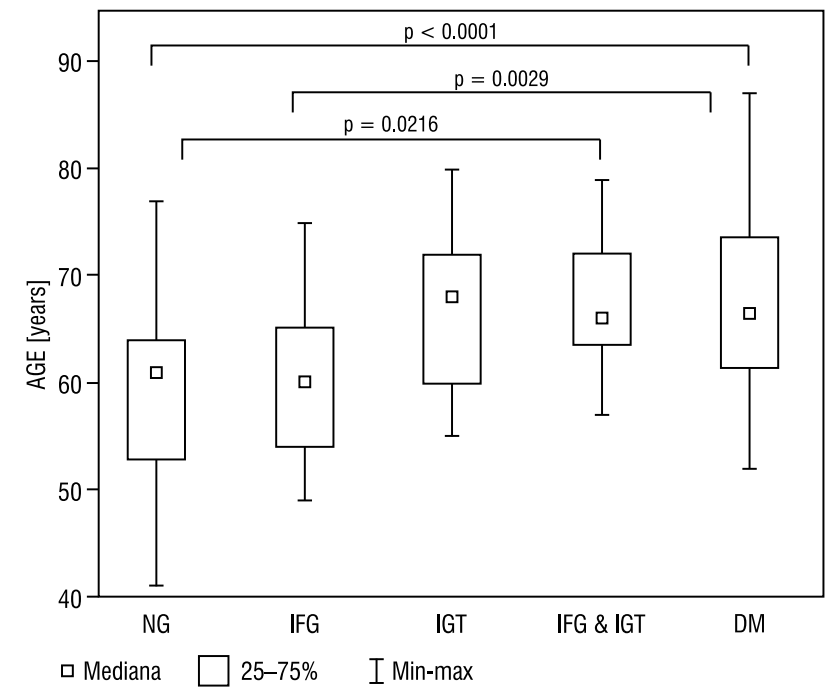

Figure 2. Age of non-functioning adrenal incidentaloma (NFAIs) patients with normoglycaemia (NG), impaired fasting glucose (IFG), impaired glucose tolerance (IGT), IFG E IGT, and diabetes mellitus (DM)

Rycina 2. Wiek pacjentów z nieczynnymi hormonalnie guzami nadnerczy z prawidłowa glikemia (NG), nieprawidtowa glikemiq na czczo (IFG), nieprawidtowa tolerancja glukozy (IGT), IFG E IGT oraz cukrzyca (DM)

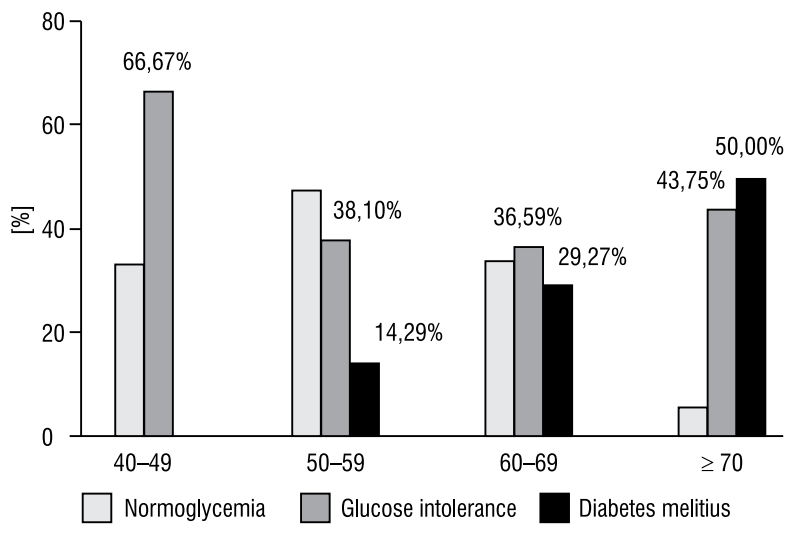

Figure 3. Prevalence of glucose disturbances in females by age

Rycina 3. Występowanie zaburzeń gospodarki węglowodanowej u kobiet w zależności od wieku

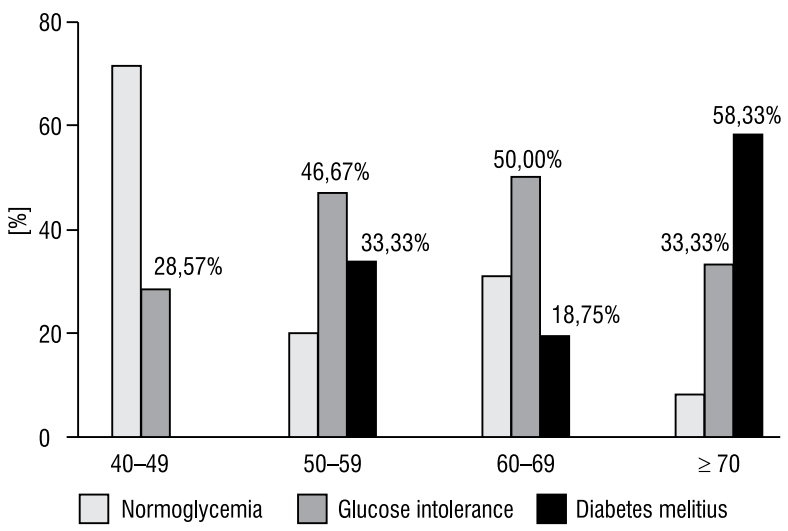

Figure 4. Prevalence of glucose disturbances in males by age

Rycina 4. Występowanie zaburzeń gospodarki węglowodanowej u mężczyzn w zależności od wieku 
Table I. Selected clinical, biochemical, and hormonal features in patients with non-functioning adrenal incidentalomas Tabela I. Wybrane cechy kliniczne, biochemiczne i hormonalne u pacjentów z hormonalnie nieczynnymi incydentaloma nadnerczy

\begin{tabular}{|c|c|c|c|c|c|c|}
\hline & \multirow{2}{*}{$\begin{array}{l}1 \\
\text { Normal glucose } \\
\text { tolerance } \\
(\mathrm{n}=39)\end{array}$} & \multirow{2}{*}{$\begin{array}{l}2 \\
\text { Glucose intolerance } \\
\text { (IFG + IGT) } \\
(\mathbf{n}=\mathbf{5 2})\end{array}$} & \multirow{2}{*}{$\begin{array}{l}3 \\
\text { Diabetes } \\
\text { mellitus } \\
(n=40)\end{array}$} & \multicolumn{3}{|c|}{ p value } \\
\hline & & & & 1 vs. 2 & 1 vs. 3 & 2 vs. 3 \\
\hline Age [years] & $58.8 \pm 8.3$ & $63.3 \pm 7.6$ & $67.4 \pm 8.2$ & $p=0.0347$ & $p<0.0001$ & $p=0.0585$ \\
\hline $\operatorname{Sex}[M / F]$ & $14 / 25$ & $23 / 29$ & $15 / 25$ & & & \\
\hline BMI [kg/m²] & $27.6 \pm 4.0$ & $30 \pm 4.6$ & $31.7 \pm 6.7$ & $p=0.1059$ & $p=0.0015$ & $p=0.3123$ \\
\hline Waist circumference [cm] & $93.8 \pm 11.5$ & $101.5 \pm 11.6$ & $103 \pm 15.1$ & $p=0.0189$ & $p=0.0037$ & $p=0.8592$ \\
\hline SBP [mmHg] & $131.3 \pm 17.9$ & $133,9 \pm 22.6$ & $145 \pm 18.2$ & $p=0.8264$ & $p=0.0068$ & $p=0.0354$ \\
\hline $\mathrm{DBP}[\mathrm{mmHg}]$ & $81.7 \pm 11.6$ & $80.7 \pm 11.2$ & $82.7 \pm 12.2$ & & $p=0.7441$ & \\
\hline Fasting glucose $[\mathrm{mg} / \mathrm{dL}]^{*}$ & $90.0(78.0 ; 99.0)$ & $105.0(101.0 ; 108.0)$ & $\begin{array}{l}113.5(103.0 ; \\
135.5)\end{array}$ & $p<0.0001$ & $p<0.0001$ & $p<0.0001$ \\
\hline Fasting insulin $[\mu \mathrm{lU} / \mathrm{mL}]^{*}$ & $8.4(5.9 ; 12.6)$ & $10.6(7.5 ; 14.0)$ & $9.5(5.9 ; 15.5)$ & & $p=0.1213$ & \\
\hline $\mathrm{HbA1c}[\%]^{*}$ & $5.5(5.3 ; 5.6)$ & $5.7(5.5 ; 5.9)$ & $6.3(5.8 ; 6.8)$ & $p=0.0304$ & $\mathrm{p}<0.0001$ & $p=0.0001$ \\
\hline HOMA-IR* & $1.74(1.28 ; 2.77)$ & $2.84(1.87 ; 3.71)$ & $2.58(1.50 ; 4.20)$ & $p=0.0032$ & $p=0.0332$ & $p=1.0$ \\
\hline QUICKI* & $0.305(0.304 ; 0.307)$ & $0.299(0.298 ; 0.301)$ & $\begin{array}{l}0.296 \\
(0.290 ; 0.300)\end{array}$ & $\mathrm{p}<0.0001$ & $\mathrm{p}<0.0001$ & $p=0.2168$ \\
\hline TyG index & $8.57 \pm 0.50$ & $8.90 \pm 0.39$ & $9.01 \pm 0.40$ & $p=0.0021$ & $\mathrm{p}<0.0001$ & $p=0.4513$ \\
\hline UFC $[\mu \mathrm{g} / \text { day }]^{*}$ & $38.0(30.0 ; 69.0)$ & $49.1(26.3 ; 72.8)$ & $40.2(23.4 ; 50.4)$ & & $\mathrm{p}=0.2842$ & \\
\hline $\begin{array}{l}\text { Midnight serum cortisol } \\
{[\mu \mathrm{g} / \mathrm{dL}]^{*}}\end{array}$ & $3.0(2.2 ; 4.6)$ & $3.7(2.4 ; 6.4)$ & $4.0(3.1 ; 5.4)$ & & $p=0.2974$ & \\
\hline $\begin{array}{l}\text { Post-dexamethasone } \\
\text { serum cortisol }[\mu \mathrm{g} / \mathrm{dL}]^{*}\end{array}$ & $1.42 \pm 0.62$ & $1.42 \pm 0.60$ & $1.49 \pm 0.60$ & & $p=0.8040$ & \\
\hline ACTH $[p g / m L]^{*}$ & $15.5(9.8 ; 30.1)$ & $15.5(9.3 ; 26.0)$ & $22.1(12.2 ; 30.9)$ & & $p=0.2566$ & \\
\hline Tumour size $[\mathrm{mm}]^{*}$ & $19.0(12.0 ; 23.0)$ & $20.0(15.5 ; 29.0)$ & $17.0(12.0 ; 25.5)$ & & $p=0.1587$ & \\
\hline Unilateral/bilateral tumours & $31 / 8$ & $39 / 13$ & $29 / 11$ & & & \\
\hline
\end{tabular}

Values are expressed as mean $\pm \mathrm{SD}$, unless otherwise indicated. ${ }^{*}$ Values are median $\left(25^{\text {th }}\right.$ and $75^{\text {th }}$ percentile). IFG — impaired fasting glucose; IGT — impaired glucose tolerance; BMI — body mass index; SBP — systolic blood pressure; DBP — diastolic blood pressure; HbA1c — glycated haemoglobin A1c; HOMA-IR — homeostasis model assessment; QUICKI — quantitative insulin sensitivity check index; TyG — the product of fasting triglyceride and glucose; UFC — 24-hour urinary free cortisol; $\mathrm{ACTH}$ - adrenocorticotropin

( $\mathrm{p}=0.0032$ for HOMA-IR, $\mathrm{p}<0.0001$ for QUICKI, $\mathrm{p}=0.0021$ for TyG index), and between normoglycaemic and overt diabetic individuals ( $\mathrm{p}=0.0332$ for HOMA-IR, $\mathrm{p}<0.0001$ for QUICKI and TyG index). Subgroups with impairments in glucose tolerance presented no statistical difference in IR markers ( $p=1.0$ for HOMA-IR, $\mathrm{p}=0.2168$ for QUICKI, $\mathrm{p}=0.4513$ for TyG index).

Anthropometric and selected biochemical and hormonal characteristics of the target population are shown in Table I.

Generally, there was no significant correlation either between fasting glucose, insulin resistance indices and tumour size, midnight serum cortisol, and post-dexamethasone cortisol. Interestingly in normoglycaemic individuals midnight serum cortisol negatively correlated with adrenal tumour size $(R=-0.32$, $\mathrm{p}=0.0438)$ and TyG index $(\mathrm{R}=-0.42, \mathrm{p}=0.0070)$. There was no such correlation in the remaining subgroups or between cortisol and HOMA-IR or QUICKI. Moreover, in diabetic subjects, post-dexamethasone serum cortisol positively correlated with tumour size $(R=0.43$, $p=0.0084)$ and negatively correlated with HOMA-IR $(\mathrm{R}=-0.43, \mathrm{p}=0.0159)$. Some positive correlation between tumour size and post-dexamethasone serum cortisol was shown also in the glucose intolerant group $(\mathrm{R}=0.27, \mathrm{p}=0.0689)$ but not in the normoglycaemic group $(R=0.10, p=0.5542)$.

\section{Discussion}

Our study shows that insulin resistance and related complications such as altered glucose metabolism are common in patients with hormonally inactive adrenal incidentalomas. The participants were not adjusted for body weight or age, and no control group was included, which is the main limitation of the study because we examined consecutive, unselected patients with adrenal incidentalomas. 
In our study the incidence of diabetes mellitus in NFAIs occurred 4.5 times more often ( $30.5 \%$ vs. $6.7 \%)$ and impaired fasting glucose was 2.2-fold higher (35\% vs. $15.6 \%$ ) than in the general Polish population [12]. Similarly, according to the Diabetes Atlas, the prevalence of diabetes in Poland was about $6-7 \%$. When dividing the European population by age (20-29, 30-39, $40-49,50-59,60-69,70-79$ years) and sex, the highest percentage of diabetes (20-25\%) was among males aged 60 years and over and females aged 70 years and over [13]. In our incidentaloma patients there was about a 1.5-2.0-fold higher occurrence rate of glucose aberrations in three subgroups divided by aged (50-59, 60-69, $\geq 70$ years). Moreover, obesity and arterial hypertension were strong predictors of alterations in glucose metabolism, such as in the NATPOL 2011 Study. In prior studies higher prevalence of metabolic syndrome parameters was reported in NFAI patients [14].

Previously, it was shown that patients with NFAIs have a high prevalence of disturbed glucose tolerance, lower than that described for Cushing's syndrome, but higher than expected. Fernandez-Real et al. [15] revealed that cortisol concentration, both basal and post-dexamethasone, was similar in patients with normal and altered glucose tolerance. Our study also did not expose a significant difference in cortisol secretory in all subgroups. However, these results are not sufficient argument against the possibility of the influence of cortisol production on glucose metabolism. We cannot rule out that methods used for measurement of glucocorticoids are not sensitive enough to detect their subtle excess.

A study by Ivović et al. [16] showed that there was no difference between subjects with subclinical Cushing syndrome (SCS) and NFAIs for all tested indices of insulin resistance (IR): HOMA, QUICKI, TyG, ISI-composite, and $\mathrm{G} / \mathrm{I}$, and that post-dexamethasone serum cortisol cannot be used as a predictor of HOMA. In support of their findings, Morelli et al. unveiled no differentiation in the presence of arterial hypertension, diabetes mellitus, dyslipidaemia, abdominal obesity, or metabolic syndrome between the two above groups. Moreover, Morelli et al. suggested that glucocorticoid receptor polymorphism in patients with adrenal incidentaloma may play a role in determining the metabolic complications related to overt cortisol excess [17].

Midorikawa et al. [18] demonstrated an improvement in blood pressure, glucose tolerance, and insulin resistance after adrenalectomy in patients with SCS and NFAIs, suggesting that metabolic disorder may be associated with adrenocortical adenoma and might be part of its pathophysiology even if the tumour has been diagnosed as non-functioning by endocrinological examination. Muscogiuri et al. revealed correlation between insulin resistance and free urinary cortisol, $\mathrm{ACTH}$, and serum cortisol after 1-mg dexamethasone suppression, demonstrating that although there are no overt clinical abnormalities, there may be subtle disturbances of cortisol steroid secretion. They also found correlation between degree of insulin resistance and adrenal tumour size, prompting the mass size as the most powerful predictor of insulin resistance. Moreover, there was the hypothesis that clinically undetectable hypercortisolism might be responsible for insulin resistance and hyperinsulinaemia might induce growth of tumour [2]. In our study we did not find differences in metabolic symptoms in patients with NFAIs in relation to the size of the tumour, which is in agreement with the study by Lazurova et al. [19].

\section{Conclusions}

The main outcome of this study was a remarkably higher prevalence of disturbed glucose tolerance among subsequent unselected patients with non-functioning adrenal adenomas than that found in the general Polish population. According to the present data, the unexpected finding of adrenal tumour should encourage clinicians to diagnose early and treat possible abnormalities in glucose homeostasis.

\section{References}

1. Nawar R, Aron D. Adrenal incidentalomas - a continuing management dilemma. Endocr Relat Cancer. 2005; 12(3): 585-598, doi: 10.1677/ erc.1.00951, indexed in Pubmed: 16172193.

2. Muscogiuri G, Sorice GP, Prioletta A, et al. The size of adrenal incidentalomas correlates with insulin resistance. Is there a cause-effect relationship? Clin Endocrinol (Oxf). 2011; 74(3): 300-305, doi: 10.1111/j.13652265.2010.03928.x, indexed in Pubmed: 21070314.

3. Reincke M, Fassnacht M, Väth S, et al. Adrenal incidentalomas: a manifestation of the metabolic syndrome? Endocr Res. 1996; 22(4): 757-761, indexed in Pubmed: 8969938.

4. Terzolo M, Pia A, Alì A, et al. Adrenal incidentaloma: a new cause of the metabolic syndrome? J Clin Endocrinol Metab. 2002; 87(3): 998-1003, doi: 10.1210/jcem.87.3.8277, indexed in Pubmed: 11889151.

5. Gutch M, Kumar S, Razi SM, et al. Assessment of insulin sensitivity/resistance. Indian J Endocrinol Metab. 2015; 19(1): 160-164, doi: 10.4103/22308210.146874, indexed in Pubmed: 25593845.

6. Guerrero-Romero F, Simental-Mendía LE, González-Ortiz M, et al. The product of triglycerides and glucose, a simple measure of insulin sensitivity. Comparison with the euglycemic-hyperinsulinemic clamp. J Clin Endocrinol Metab. 2010; 95(7): 3347-3351, doi: 10.1210/jc.2010-0288, indexed in Pubmed: 20484475.

7. Vasques AC, Novaes FS, de Oliveira Md, et al. TyG index performs better than HOMA in a Brazilian population: a hyperglycemic clamp validated study. Diabetes Res Clin Pract. 2011; 93(3): e98-e9e100, doi: 10.1016/j. diabres.2011.05.030, indexed in Pubmed: 21665314.

8. PTD. Zalecenia kliniczne dotyczące postępowania u chorych na cukrzycę 2016. Diab Klin. 2016; 5(supl. A).

9. Association American Diabetes. Standards of Medical Care in Diabetes — 2016. Diabetes Care. 2016; 39(supl. 1).

10. Navarro-González D, Sánchez-Íñigo L, Pastrana-Delgado J, et al. Triglyceride-glucose index (TyG index) in comparison with fasting plasma glucose improved diabetes prediction in patients with normal fasting glucose: The Vascular-Metabolic CUN cohort. Prev Med. 2016; 86: 99-105, doi: 10.1016/j.ypmed.2016.01.022, indexed in Pubmed: 26854766.

11. Lee SH, Han K, Yang HK, et al. A novel criterion for identifying metabolically obese but normal weight individuals using the product of triglycerides and glucose. Nutr Diabetes. 2015; 5: e149, doi: 10.1038/ nutd.2014.46, indexed in Pubmed: 25915739. 
12. Rutkowski M, Bandosz P, CzupryniakL, et al. Prevalence of diabetes and impaired fasting glucose in Poland--the NATPOL 2011 Study. Diabet Med. 2014; 31(12): 1568-1571, doi: 10.1111/dme.12542, indexed in Pubmed: 24975751.

13. IDF. 2015 Diabetes Atlas. http://www.diabetesatlas.org.

14. Tuna MM, Imga NN, Doğan BA, et al. Non-functioning adrenal incidentalomas are associated with higher hypertension prevalence and higher risk of atherosclerosis. J Endocrinol Invest. 2014; 37(8): 765-768, doi: 10.1007/s40618-014-0106-5, indexed in Pubmed: 24923898.

15. Fernández-Real JM, Engel WR, Simó R, et al. Study of glucose tolerance in consecutive patients harbouring incidental adrenal tumours. Study Group of Incidental Adrenal Adenoma. Clin Endocrinol (Oxf) 1998; 49(1): 53-61, doi: 10.1046/j.1365-2265.1998.00437.x, indexed in Pubmed: 9797847.

16. Ivović M, Marina LV, Vujović S, et al. Nondiabetic patients with either subclinical Cushing's or nonfunctional adrenal incidentalomas have lower insulin sensitivity than healthy controls: clinical implications. Metabolism. 2013; 62(6): 786-792, doi: 10.1016/j.metabol.2012.12.006, indexed in Pubmed: 23332445.

17. Morelli V, Donadio F, Eller-Vainicher C, et al. Role of glucocorticoid receptor polymorphism in adrenal incidentalomas. Eur J Clin Invest. 2010; 40(9): 803-811, doi: 10.1111/j.1365-2362.2010.02330.x, indexed in Pubmed: 20584071.

18. Midorikawa S, Sanada H, Hashimoto S, et al. The improvement of insulin resistance in patients with adrenal incidentaloma by surgical resection. Clin Endocrinol (Oxf). 2001; 54(6): 797-804, indexed in Pubmed: 11422115

19. Lazúrová I, Spišáková D, Wagnerová H, et al. Clinically silent adrenal adenomas - their relation to the metabolic syndrome and to GNB3 C825T gene polymorphism. Wien Klin Wochenschr. 2011; 123(19-20): 618-622, doi: 10.1007/s00508-011-0064-2, indexed in Pubmed: 21979884 